\title{
The Correlation Between the Opponent's Error with the Team Victory of the Volleyball National Team on 2019 Peace Cup Participants
}

\author{
Tirto Apriyanto \\ Faculty of Sports Science \\ Jakarta State University \\ Indonesia \\ tapriyanto@unj.ac.id
}

\author{
Muhammad Ilham \\ Faculty of Sports Science \\ Jakarta State University \\ Indonesia \\ milham@unj.ac.id
}

\begin{abstract}
This study aimed to determine the correlation between opponent's error with the team victory of the volleyball national team on 2019 Peace Cup participants. This research method used a survey method with correlational techniques, which was a study to collect data obtained from the results of the Peace Cup friendly competition using VIS (Volleyball Information System) software. The research population was all participants of the 2019 Peace Cup match, and the sample taken was the Indonesian national team of men and women. The research results obtained by the regression equation $\mathrm{Y}$ to $\mathrm{X}$ is = $16.332+1.034 X$, then obtained Fcount $=4.318>$ Ftable $=3.52$. It rejects Ho but the calculation result is significant (at $\alpha=0.05$ ). The coefficient of determination of opponent's error with winning team is $\left(r x y^{2}\right)=0.185$. This also means that $18.5 \%$ of team victory $(Y)$ are determined by opponent's error $(X)$.

Keywords: opponent error, team victory
\end{abstract}

\section{INTRODUCTION}

As far as researchers concern, a win assessment instrument that can be used to measure athletes' performance in playing volleyball is the VIS [1]. The instrument is a program to complete a match that includes statistics of each individual player up to the team. The main objective of VIS is to inform national and international media on the results of team and individual player's statistical results. Therefore, this instrument is considered to be used to assess the athlete's victory when playing volleyball in accordance with the techniques or skills performed by each individual [2].

A team can score points in four different ways: by serving, blocking, attacking or from the opponent's error. This is in accordance with the opinion according to [3] which states that points in volleyball games are scored through serving, blocking, attacking and from the opponent's error.

Based on the data collection in match statistics using the Volleyball Information System (VIS), several terms are used in recording match data. In accordance with the basic techniques carried out, later known; Servers (service performers), receivers (service receivers), setters (feeders), attackers (smash perpetrators), diggers (smash receivers) and blockers (block perpetrators). Based on these evaluation criteria, [4], the development of the game becomes more interesting and requires a lot of special abilities in each training technique.

So far, only specialist players appear to be feeders (setters) and hitters (Attacker), but now there is a defensive specialization player (libero), even initially only 1 person was allowed, but now 2 people are allowed in one team [5]. By studying the developing game patterns and the pre-veiling scoring system, the division of groups in volleyball technique is divided into 2 categories, namely; 1) Scoring Skills (techniques that produce numbers) and 2) Non-Scoring Skills (techniques that do not produce numbers) [6]

From the various activities in the match, there were points that were not derived from the techniques performed by the team itself. Some numbers are obtained as a result of the opponent's error in per-forming the technique or completing the rally, for example; service that fails or exits the field, attacks that do not manage to cross the net or fall off the field, double-touch by setters and others. This condition in the calculation of match statistics is called an opponent's error. Obtaining a number from the opponent's error is a distinct advantage for the team because the figure is obtained free of charge and the team does not spend too much energy to obtain the winning score.

Therefore, the research on the effect of opponent's error on the national team victory on the 2019 Peace Cup was carried out with the aim of finding out the contribution of the opponent's error on resulting the team's victory.

\section{METHOD}

This research method used a survey method with correlational techniques, which was a study to collect data obtained by observation on the 2019 Peace Cup match. This research was conducted at GOR Pertamina Simprug, South Jakarta from April until October 2019. The event was held on June 23rd-25th, 2019. It is called "peace" because it was initiated by 2 countries that were involved in a conflict and now just made peace which were South Korea and North Korea. In this study the entire population of the Peace Cup 2019 became the population of the research. The sample in this study used a purposive sampling technique, so that the sample was the Indonesian national team participating on the 2019 Peace Cup.

The instrument in measuring athlete anxiety was the VIS (Volleyball Infor-mation System) Software which is the official match statistics software from FIVB. The data analysis techniques in this research used SPSS ver 18.0 .

\section{RESULTS AND DISCUSSION}

From the results of data collection and analysis, the following research results are obtained: 
Opponent's error is the acquisition of numbers that are considered to benefit the team because it does not go through the process of the activities of the team itself. In other words, the score obtained from the opponent's error is the 'free' score. Technically, this score cannot be forced to be obtained, given the error is an event that is also not expected by the opposing team. But non-technically, the team can make an effort in order to obtain it through various ways.

Based on the results of testing the above hypothesis, opponent's error directly affects the team victory. This is consistent with the opinion [7]. When looking at the results of different skills on the screen in volleyball matches (serving, blocking, attacking, receiving, baiting and defending), it is clear that the team that makes the fewest mistakes is the most potential to win the match.

Opponent's errors are mistakes made by opponents and benefit the team. However, researchers find out several factors that cause opponent's error is caused by some good quality techniques. For example, the opponent is not able to do a good receive because the quality of service that is launched is very sharp and difficult. Opponents are not able to return the attack because the spike is done precisely and accurately.

Based on the explanation above, each team tries to reduce the mistakes made during the match. This is in accordance with the opinion [8] which explains that to be a champion, any team must develop good playing and technical skills. Trying to make as few mistakes as possible in playing techniques to give a chance to win.

\section{Winning in Volleyball}

Volleyball game is played with the aim of obtaining a winning score in accordance with applicable game rules. Winning that starts from rally, set, game, round, until becoming a champion is a series of win scores that are built from individual techniques to team wins. Judging the win of the game in volleyball is done by recording all the activities that occur in each rally that occurs during the match. The conditions for a team's winning score are as follows [9]

\section{1) Getting a score/number}

Scores are the result of a rally. Scores are printed in various ways - by players so that opponents who make mistakes, "receive the ball", "landing the ball", etc., in one rally. Rally in volleyball games is the time/event between service and the end of the game (dead ball) [10]. In other words, the team successfully lands the ball on the opponent's playing field; the opposing team makes an error (opponent's error). If two or more errors occur in a row, then only the first error is applied. If two or more errors occur simultaneously, it is called a double error (double vault), and the rally is repeated.

\section{2) Winning a Set}

One set (except for the fifth set) is won by the first team to score 25 with a minimum difference of two points. At a score of 24-24, the game is continued until a diffe-rence of two numbers is reached (26-24; $27-25$, until infinity).

\section{3) Winning the Match}

The match is won by the team that wins three sets of games (3- 0 or 3-1). In the 2-2 win set condition, the 5 th set is played up to a score of 15 , a minimum difference of two points. In the score 14-14, the game is continued until a difference of two numbers is reached (16-14; 17-15, to infinity). rotation/position violations, card violation, and other case due to no player taking/continuing the ball. 


\section{REFERENCES}

Opponent's error is a condition in which the team gets a score which is caused by an error made by the opponent. Opponent's error is a score of 'free' obtained because the team relatively does not make much effort in getting the score, except for certain conditions, such as the opponent's attack that fails due to the optimal block. From a number of conditions, the opponent's error which often happens is that the opponent's service fails, and from this, it comes the term 'free score' because the team really does not do any activity in the rally. It has been explained in the framework of the previous theory; although this score is obtained passively, but there are some efforts that can be done in order to obtain a score from opponent's error.

\section{CONCLUSION}

From the research, it can be concluded that there is a significant relationship between opponent's error and team victory which contributed as much as $18.5 \%$. This also means that $18.5 \%$ of team victory $(\mathrm{Y})$ is determined by the opponent's error $(\mathrm{X})$. This means that the higher opponent's errors that occur in each set of wins will be able to produce a team victory in every match.
[1] FIVB, VIS Staff Guidelines, FIVB, 2005.

[2] M. E. Quiroga, J. García-Manso, D. Rodríguez-Ruiz, S. Sarmiento, Y. De Saa, and M. P Moreno, "Relation between in-game role and service characteristics in elite women's volleyball," Journal of Strength and Conditioning Research, vol. 24, no. 9, 2010, pp. 2316-2321.

[3] M. Häyrinen, T. Hoivala, and M. Blomqvist, "Differences between winning and losing teams in men's european top-level volleyball," 2004

[4] J. M. Palao, J. A. Santos, and A. Ureña, "Effect of team level on skill performance in volleyball," International Journal of Performance Analysis of Sport, vol 4. no. 2, 2004, pp. 50-60.

[5] PBVSI, Volleyball Game Rules, Jakarta, 2014.

[6] A. Otávio and G. Ferreira, "Evaluation of scoring skills and non scoring skills in the Brazilian superleague women's volleyball," Monten. J. Sports Sci. Med. vol. 5 no. 2, 2016, pp. 25-31.

[7] J. Castro, A. Souza, and I Mesquita, "Attack efficacy in volleyball: Elite male teams," Perceptual and Motor Skills, vol. 113, no. 2, 2014. pp. 395-408

[8] H. Setijono, "Analysis on players' playing skills during the national volleyball league," Proliga, vol. 247, 2018, pp. 583-587.

[9] T. Apriyanto, Buku Ajar Teknik Permainan Bola Voli, Jakarta: FIK UNJ, 2015.

[10] FIVB. Official Volleyball Rules 2015-2016 in 34th FIVB Congress. (Online) http://www.fivb.org/en/Refereeing-Rules/documents/, 2014. 